\title{
Effect of the number of thermocycles on microleakage of resin composite restorations
}

\section{Efeito do número de ciclos térmicos na microinfiltração de restaurações de resina composta}

\author{
Flávia Bittencourt Pazinatto* \\ Bruno Barbosa Campos** \\ Leonardo César Costa* \\ Maria Teresa Atta***
}

\begin{abstract}
Thermocycling simulates, in vitro, thermal changes that occur in the oral cavity. The aim of this study was to evaluate the influence of the number of cycles on microleakage. Class V cavities $(1.5 \mathrm{~mm}$ deep, $3 \mathrm{~mm}$ in height and $3 \mathrm{~mm}$ in width) were prepared in bovine teeth, restored with a Single Bond/Z250 restorative system (3M/ESPE) and then divided into five groups of ten teeth each: group 1 was not thermocycled (control group), and groups 2, 3, 4 and 5 were thermocycled $500,1,000,2,500$ and 5,000 times, respectively $\left(5^{\circ}-55^{\circ} \pm 2^{\circ} \mathrm{C}, 15 \mathrm{~s}\right.$ dwell time). The teeth were immersed in $0.5 \%$ basic fuchsin aqueous solution for $24 \mathrm{~h}$, sectioned and the sections with the highest degree of microleakage were selected, scanned and the extent of dye penetration was measured by the ImageTool program. The results submitted to one-way ANOVA showed no significant differences between the groups $(p>0.05)$. The averages of microleakage values in millimeters were: group 1 (3.92); group 2 (3.13); group 3 (4.48); group 4 (4.33) and group 5 (3.42). Thus, it was concluded that there is no relation between the increase of the number of cycles and the increase in microleakage.
\end{abstract}

DESCRIPTORS: Dental leakage; Composite resins.

\begin{abstract}
RESUMO: A ciclagem térmica tem por objetivo simular, in vitro, as mudanças térmicas intra-orais que ocorrem clinicamente. Sendo o seu efeito bastante discutido, o presente trabalho tem como objetivo avaliar a relação da ciclagem térmica e o número de ciclos na infiltração marginal. Foram confeccionadas cavidades classe $\mathrm{V}$ com dimensões de $3 \mathrm{~mm}$ de altura, $3 \mathrm{~mm}$ de largura e 1,5 $\mathrm{mm}$ de profundidade, em dentes bovinos. Os dentes foram restaurados com o sistema Single Bond/Z250 (3M/ESPE) e, então, divididos em 5 grupos de 10 dentes cada: grupo 1 (controle) sem ciclagem; grupos 2 , 3, 4 e 5 com $500,1.000,2.500$ e 5.000 ciclos, respectivamente $\left(5^{\circ}-55^{\circ} \pm 2^{\circ} \mathrm{C}, 15\right.$ segundos por banho). A seguir, os dentes foram seccionados e analisados em microscópio com $100 \mathrm{X}$ de aumento para a escolha da fatia mais infiltrada, que foi escaneada e quantificada pelo programa ImageTool. Os dados submetidos ao teste ANOVA a um critério não apresentaram diferença significante $(\mathrm{p}>0,05)$, resultando em valores médios de infiltração em milimetros: grupo 1 $(3,92)$, grupo $2(3,13)$, grupo $3(4,48)$, grupo $4(4,33)$ e grupo $5(3,42)$. A análise dos dados permitiu concluir que não há relação entre o aumento do número de ciclos e o aumento da infiltração marginal.
\end{abstract}

DESCRITORES: Infiltração dentária; Resinas compostas.

\section{INTRODUCTION}

The development of dental materials and operative techniques over the last few years and a better understanding of dentin substrate characteristics has provided a significant decrease in the marginal microleakage of restorations. However, resin composites present polymerization shrinkage and different linear coefficients of thermal expansion from the tooth. These factors affect the clinical performance of resin composite restorations by dis- rupting the adhesive interface, resulting in microleakage. Additionally, in the oral cavity the restorations are subjected to both thermal and mechanical stress that also contribute to the increase of marginal microleakage.

Microleakage tests are the most frequently used laboratory tests to study the mechanisms that may minimize, or eliminate, the leakage around dental restorations. Although the clinical relevance of the leakage tests does not always correlate precisely with the clinical situation, a microleakage test is a

*PhD Students; ***PhD, Professor - Department of Operative Dentistry, Endodontics and Dental Materials, Bauru School of Dentistry, University of São Paulo.

**MSc, Health Science Institute, Paulista University, Goiânia. 
Pazinatto FB, Campos BB, Costa LC, Atta MT. Effect of the number of thermocycles on microleakage of resin composite restorations. Pesqui Odontol Bras 2003;17(4):337-41.

useful method in the investigation of resin composite restorations.

Thermocycling regimens may simulate more appropriately the clinical situation ${ }^{21}$. However, thermocycling in resin composite microleakage tests is very questionable $e^{13,15,24}$. The aim of this study was to evaluate the influence of thermocycles on the microleakage of resin composite restorations.

\section{MATERIAL AND METHODS}

Fifty bovine incisors with no structural defects were selected, debrided and stored in 10\% thymol solution at $4^{\circ} \pm 2^{\circ} \mathrm{C}$ until cavity preparations were carried out. The use of bovine teeth as a substitute for human teeth is a suitable alternative in microleakage studies ${ }^{19}$ and have the advantage of being readily available ${ }^{18,19}$, similar in age, and posing a lesser hazard for infection control ${ }^{4}$.

Flat dentin surfaces were created by removing the enamel with 80-grit silicon carbide paper (Norton, Vinhedo, Brazil) under running water, so all the cavity margins were in dentin. In each tooth, $2 \mathrm{~mm}$ above the cementum-enamel junction, class $\mathrm{V}$ preparations $(1.5 \mathrm{~mm}$ deep, $3 \mathrm{~mm}$ in height and $3 \mathrm{~mm}$ in width) were made on the buccal surface using a 245 carbide bur (KG Sorensen Ind. Com. Ltda., Barueri, SP, Brazil) at high speed and under water coolant. The cavity walls were finished by using hand instruments. All the preparations were made by the same operator.

Restorative procedures were similar for all the cavities: dentin walls were etched with $35 \%$ phosphoric acid gel (Scotchbond Etchant, 3M/ESPE, St. Paul, MN, USA) for $15 \mathrm{~s}$ and rinsed for $30 \mathrm{~s}$. Excess water was blot-dried with a tissue paper leaving the surface visibly moist. An adhesive bond system (Single Bond, 3M/ESPE, St. Paul, MN, USA) was applied and dried with an air syringe for $10 \mathrm{~s}$ and light-cured for $10 \mathrm{~s}$. The bonded surfaces were examined to ensure that they were shiny prior to light-activation. When a matte surface was observed, additional coats of adhesive were applied. Two diagonal increments of resin composite (Z250, 3M/ESPE, St. Paul, MN, USA) were placed and light-cured for $20 \mathrm{~s}$ each increment. All specimens were stored for 6 days in deionized water at $37^{\circ} \mathrm{C}$ and then the restorations were finished and polished with Sof-Lex (3M-ESPE, St. Paul, MN, USA) sequential abrasive discs.

The teeth were randomly divided into 5 groups of 10 teeth each. Group 1 (control) was not thermocycled and was kept in deionized water at $37^{\circ} \mathrm{C}$.
The other groups were submitted to thermocycling in deionized water baths for $15 \mathrm{~s}$, at $5^{\circ}-55^{\circ} \pm 2^{\circ} \mathrm{C}$. Groups 2, 3, 4 and 5 were submitted to $500,1,000$, 2,500 and 5,000 cycles, respectively.

Thereafter, the external surfaces of each tooth were coated with nail varnish (Maybelline LLC, Dist., New York, NY, USA) leaving a $1 \mathrm{~mm}$ wide margin, around the restoration, free of varnish. Then, the teeth were immersed in deionized water for $12 \mathrm{~h}$ at $37^{\circ} \mathrm{C}$ to prevent dehydration. After that, the samples were immersed in $0.5 \%$ basic fuchsin aqueous solution for $24 \mathrm{~h}$ and rinsed under running tap water for $24 \mathrm{~h}$. The teeth were then embedded in epoxy resin (Redelease Ltda., São Paulo, SP, Brazil) and sectioned with a slow-speed water-cooled diamond saw in a section machine (Labcut 1010, Extec Corp., Enfield, CT, USA). Approximately 2 or 3 sections of $0.5 \mathrm{~mm}$ from each tooth were obtained, resulting in 4 to 6 surfaces for dye penetration analysis that were examined under a microscope at $100 \mathrm{X}$ magnification to certify that the dye penetration came from the dentin/restoration interface. The most infiltrated sections were selected for dye penetration measurement in millimeters with a computer program (ImageTool, UTHSCSA, Texas, USA), providing quantitative and parametric analysis.

\section{RESULTS}

The data were analyzed by one-way ANOVA $(\alpha=0.05)$. There was no significant difference between groups $(p=0.20)$. The mean values, in millimeters, of microleakage for each group are shown in Graph 1.

\section{DISCUSSION}

Adhesion of dental materials to enamel is a well-known reliable procedure. Bonding to dentin,

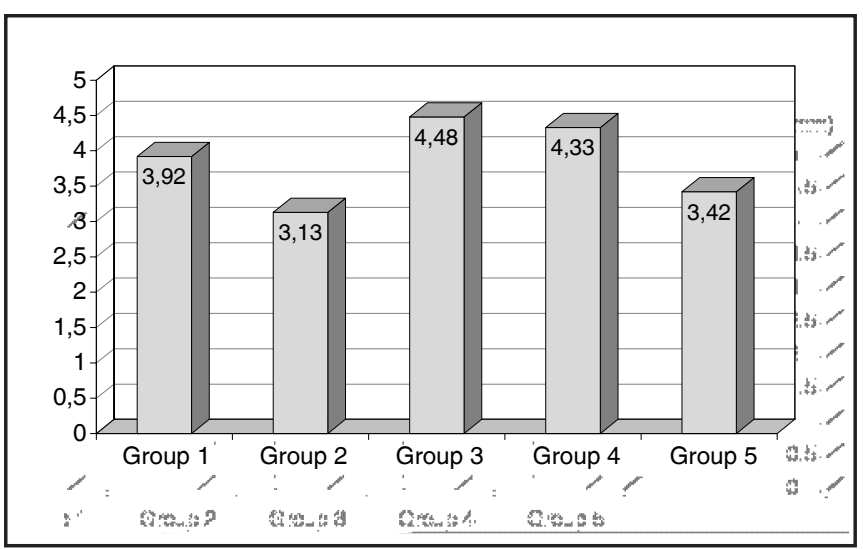

GRAPH 1 - Mean values ( $\mathrm{mm})$ of microleakage. 
Pazinatto FB, Campos BB, Costa LC, Atta MT. Effect of the number of thermocycles on microleakage of resin composite restorations. Pesqui Odontol Bras 2003;17(4):337-41.

however is somewhat more complex due to the complexity of the substrate ${ }^{5}$. Despite there being many different characteristics on dentin that hinder the mechanism of adhesion, gradual developments can be seen in the past decades, providing many benefits for dentistry. Nevertheless, microleakage along the tooth-restoration interface is still a problem observed in clinical and laboratory tests ${ }^{1}$.

The disruption of the adhesive interface, which permits fluids and bacteria to enter, maybe be a consequence of many factors such as polymerization shrinkage and linear coefficient of thermal expansion, and can result in marginal discoloration of the restorations, development of recurrent caries and pulpal pathology $y^{6,23}$.

Microleakage studies are the most commom method of detecting the causes that result in bond failure along the tooth-restoration interface ${ }^{25}$. There are many methods for detecting marginal leakage and the organic dye method was choosen for this study because of its extensive use in the literature and its ease of use ${ }^{1}$. Therefore, $0.5 \%$ basic fuchsin aqueous solution was used for microleakage evaluation. After sectioning, specimens were observed through a microscope to certify that the dye penetration had come from the dentin/restoration interface and not from another dentin path*. Then, the most infiltrated specimen of each tooth was selected and its length was measured in millimeters by a computer program. This measurement in millimeters of the microleakage is considered more acceptable than the score assessment because it permits quantitative and parametric statistical analyses of data*.

Thermocycling is a widely acceptable method used in in vitro microleakage studies ${ }^{9,10,12,16,22}$ although some researchers consider it a questionable $\operatorname{method}^{13,15,24}$. The question is about the validity and clinical significance of the thermocycling method, since the temperatures used to stress restorations may not be the real temperatures of cold and hot food/beverage tolerated by patients ${ }^{27}$.

In the thermocycling method, specimens are submitted to thermal cycles that simulate the intraoral temperature. However, the literature shows that there is a wide range in temperature extremes, transfer times between baths and dwell times $^{1,11,23}$. Thus, there is no standard for thermocycling methodology in microleakage studies, and this permits contradictory discussions and results in various laboratory studies. In some studies, the variables choosen are only restricted to the thermocycling method, and are not intended to understand the meaning of these effects ${ }^{11}$. Because of this, in the present study the temperature was standardized at $5^{\circ} \mathrm{C}-55^{\circ} \mathrm{C} \pm 2^{\circ} \mathrm{C}$ and the dwell time was $15 \mathrm{~s}$. These variables seem to be tolerated by the oral tissues and are suitable for clinical conditions. Increases in the dwell times exceed real clinical conditions and may hide the thermal isolation characteristics of the resin composites ${ }^{21}$, leaving fatigue to this material. The number of cycles used in many studies also varies and seems to be selected by convenience ${ }^{6}$. In this study, an increased number of cycles were selected for evaluation to determine if there is a direct relation with the increase of microleakage along the tooth-restoration interface.

The linear coefficient of thermal expansion has been suggested as an important factor that influences microleakage ${ }^{17}$. It is defined as the change in length per unit length of a material when its temperature is raised or lowered $1^{\circ} \mathrm{C}^{2}$. This factor is influenced by the presence and quantity of the inorganic fillers of resin composite. A great difference in the linear coefficient of thermal expansion between tooth and restorative material will alter the dimensions of the adhesive interface with temperature change ${ }^{24}$. Thus, for example, due to the high linear coefficient of thermal expansion, amalgam restorations $\left(25 \times 10^{-6}\right.$ per $\left.{ }^{\circ} \mathrm{C}\right)$ tend to shrink and expand much more than the dental structure does (dentin: $8.3 \times 10^{-6}$ per ${ }^{\circ} \mathrm{C}$; enamel: $11.4 \times 10^{-6} /{ }^{\circ} \mathrm{C}$ ), similarly to what occurs to the resin composite restorations $\left(14-50 \times 10^{-6} \text { per }{ }^{\circ} \mathrm{C}\right)^{2}$. However, while resin composite has a high linear coefficient of thermal expansion, it is an extremely good thermal insulator. This characteristic minimizes the influence of thermocycling on microleakage and makes the coefficient of thermal expansion time-dependent $^{21}$, and is different from what happens to amalgam, which is a good thermal and electric conductor $^{2}$.

The low thermal conductivity of resin composite suggests that a $15 \mathrm{~s}$ of dwell time is not sufficient to transfer the temperature through resin composite restoration to fatigue the adhesive interface and rupture it, increasing microleakage ${ }^{23}$. This was observed in the present study in all groups. Nevertheless, Crim et al. ${ }^{10}$ (1985) related that microleakage extension seemed to be independent of the

* Pazinatto, Atta. Estudos de microinfiltração: análise crítica da metodologia. (Accepted for publication in JBD - Jornal Brasileiro de Dentística \& Estética) In press. 
Pazinatto FB, Campos BB, Costa LC, Atta MT. Effect of the number of thermocycles on microleakage of resin composite restorations. Pesqui Odontol Bras 2003;17(4):337-41.

dwell time used, just because there were two experimental bath times (4 and $30 \mathrm{~s}$ ) with no difference between them. Although, in a study by Schuckar, Geurtsen $^{22}$ (1997) thermocycling with a 30 s dwell time promoted an increase in microleakage, with great dye penetration along cavities localized at the cementum-enamel junction restored without dentin adhesive systems, and below this junction with or without dentin adhesive systems. In the group restored at the cementum-enamel junction and with adhesive systems there was no improvement in cervical marginal seal. These authors justify the increase of dye penetration due to the difference in the linear coefficient of thermal expansion between tooth and restorative material, leading to an adhesive failure at cervical margin. Meanwhile, these results can be questioned by the absence of dentin adhesive systems at dentin margins, when compared to others groups, which were localized at enamel margins and were restored with adhesive systems. Also, due to the possible polymerization shrinkage of the first resin composite increment toward enamel margins, which is well known as a substrate that provides reliable and stronger adhesion to enamel than to dentin ${ }^{7,26}$.

Another study showed a gradual increase in microleakage during the 4 months of the thermocycling test ${ }^{14}$. However, the dwell times used were 2 minutes and, possibly, the dye penetration may have occured due to degradation of the adhesive interface in this period of time, and not due exclusively to the increase of thermal cycles.

In the present study, microleakage observed did not increase with an increase in the number of thermocycles. The control group (3.92) showed more microleakage than did group 2 (3.13) and group 5 (3.42), and group 3 (4.84) leaked more than group 4 (4.33). A possible explanation for these results is that the polymerization shrinkage was responsible for the microleakage values, in addition to the difficulty in forming an adequate hybrid layer in dentin, since it is considered unpredicta$b^{28}$. Other factors such as polymerization shrinkage, hygroscopic expansion, adhesive strength,

\section{REFERENCES}

1. Alani AH, Toh CG. Detection of microleakage around dental restorations: a review. Oper Dent 1997;22:173-85.

2. Anusavice KJ. Materiais dentários. $10^{\mathrm{a}}$ ed. Guanabara Koogan; 1998. p. 18-27.

3. Bijella MFB, Bijella MFTB, Silva SMB. In vitro quantitative evaluation of marginal microleakage in class II restorations linear coefficient of thermal expansion ${ }^{6}$, elastic modulus and thermal difusibility ${ }^{23}$, and a suitable hybrid layer have been also associated to the marginal seal of resin composite restorations. These aspects require further studies to improve the understanding of microleakage.

Various microleakage studies that compared thermocycled and non-thermocycled groups $\mathrm{s}^{3,6,21,27,28}$ and also the different numbers of cycles $^{8,25}$ observed no statistically significant difference. These results suggest that the thermocycling method does not influence the microleakage of resin composite restorations. Thus, this laboratorial method is not a suitable test to simulate the real significance of temperature changes in clinical conditions. However, in some studies ${ }^{9,10,12,16,22}$ there were significant differences in marginal microleakage of resin composite restorations between thermocycled and non-thermocycled groups. Nevertheless, some authors suggest that the thermal cycling test per se does not influence microleakage of resin composite restorations. This is demonstated by the study of Rigsby et al. ${ }^{20}$ (1992), that showed that microleakage was significantly higher along cementum margins stressed by both thermocycling and load cycling, different to what was observed when thermocycling and load cycling were compared alone.

The results of this research showed no statistically significant difference between experimental and control groups. No evident relation between an increased number of cycles and microleakage of resin composite restorations was observed.

\section{CONCLUSIONS}

Based on the analysed data, it can be concluded that there is no direct relation between the use of the thermocycling test and an increase of microleakage of resin composite restorations. The number of thermocycles did not increase microleakage.

\section{ACKNOWLEDGEMENTS}

This work was partially supported by a CAPES and CNPq grant (132146/2001-0). confected with a glass ionomer cement and two composite resins. Pesqui Odontol Bras 2001;15:277-82.

4. Burrow MF, Sano H, Nakajima M, Harada N, Tagami J. Bond strength to crown and root dentin. Am J Dent 1996;9:223-9. 
Pazinatto FB, Campos BB, Costa LC, Atta MT. Effect of the number of thermocycles on microleakage of resin composite restorations. Pesqui Odontol Bras 2003;17(4):337-41.

5. Carvalho RM. Adesivos dentinários: fundamentos para aplicação clínica. Rev Dent Rest 1998;1:62-96.

6. Chan MF, Glyn Jones JC. Significance of thermal cycling in microleakage analysis of root restorations. J Dent 1994; 22:292-5.

7. Crim GA, Chapman KW. Effect of placement techniques on microleakage of a dentin-bonded composite resin. Quintessence Int 1986;17:21-4.

8. Crim GA, Garcia-Godoy F. Microleakage: the effect of storage and cycling duration. J Prosthet Dent 1987;57:574-6.

9. Crim GA, Mattingly SL. Evaluation of two methods for assessing marginal leakage. J Prosthet Dent 1981;45:160-3.

10. Crim GA, Swartz ML, Phillips RW. Comparison of four thermocycling techniques. J Prosthet Dent 1985;53:50-3.

11. Gale MS, Darvell BW. Thermal cycling procedures for laboratory testing of dental restorations. J Dent 1999; 27:89-99.

12. Hakimeh S, Vaidyanathan J, Houpt ML, Vaidyanathan TK, von Hagen S. Microleakage of compomer class V restorations: effect of load cycling, thermal cycling, and cavity shape differences. J Prosthet Dent 2000;83:194-203.

13. Harper RH, Schnell RJ, Swartz ML, Phillips RW. In vivo measurements of thermal diffusion through restorations of various materials. J Prosthet Dent 1980;43:180-5.

14. Iwase H, Momoi Y, Asanuma A, Yanagisawa K, Khono A. Marginal leakage of composite resin gradually increased with thermal cycling. J Dent Res 1989;68:923.

15. Kidd EA, Harrington E, Grieve AR. The cavity sealing ability of composite restorations subjected to thermal stress. J Oral Rehabil 1978;5:279-86.

16. Litkowski LJ, McDonald NJ, Swierczewski M. A comparison of thermalcycling methods for evaluation microleakage. J Dent Res 1989;68:207.

17. Nelsen RJ, Wolcoot RB, Paffenbarger GC. Fluid exchange at the margins of dental restorations. J Am Dent Assoc 1952;44:288-95.
18. Pereira PNR, Yamada T, Inokoshi S, Burrow MF, Sano H, Tagami J. Adhesion of resin-modified glass ionomer cements using resin bonding systems. J Dent 1998; 26:479-85.

19. Reeves GW, Fitchie JG, Hembree Jr JH, Puckett AD Microleakage of new dentin bonding systems using human and bovine teeth. Oper Dent 1995;20:230-5.

20. Rigsby DF, Retief DH, Bidez MW, Russel CM. Effect of axial load and temperature cycling on microleakage of resin restorations. Am J Dent 1992;5:155-9.

21. Rossomando KJ, Wendt SL. Thermocycling and dwell times in microleakage evaluation for bonded restorations. Dent Mater 1995;11:47-51.

22. Schuckar M, Geurtsen W. Proximo-cervical adaptation of class II composite restorations after thermocycling: a quantitative and qualitative study. J Oral Rehabil 1997; 24:766-75.

23. Shortall AC. Microleakage, marginal adaptation and composite resin restorations. Br Dent J 1982;153:223-7.

24. Trowbridge HO. Model systems for determining biologic effects of microleakage. Oper Dent 1987;12:164-72.

25. Veronezi MC. Influência da ciclagem térmica e do método de avaliação da microinfiltração em restaurações de resina composta [Tese de Doutorado]. São Paulo: Faculdade de Odontologia de Bauru da USP; 2000.

26. Versluis A, Tantbirojn D, Douglas WH. Do dental composites always shrink toward the light? J Dent Res 1998;77:1435-45.

27. Wendt SL, McInnes PM, Dickinson GL. The effect of thermocycling in microleakage analysis. Dent Mater 1992;8:181-4.

28. Wibowo G, Stockton L. Microleakage of class II composite restorations. Am J Dent 2001;14:177-85.

Recebido para publicação em 19/12/02 Enviado para reformulação em 07/07/03 Aceito para publicação em 18/09/03 